\title{
The epidemic that wasn't Beriberi in Bangka and the Netherlands Indies
}

\author{
Mary Somers Heidhues
}

Perhaps all Dutch schoolchildren learn about Dr Eijkman's chickens. By feeding the fowl either paddy, brown rice, or white rice, ${ }^{1}$ he was able to indicate that a diet of white rice caused a paralysis of the legs that resembled the nerve damage experienced by victims of the puzzling human disease called beriberi. The material in the bran or pericarp (zilvervlies) of the rice, which was removed by industrial milling, protected the chickens from what he called polyneuritis gallinarum, chicken polyneuritis, and, by a later extension, human beriberi. His insights, his good luck, and not least, his meticulous record-keeping earned him a Nobel Prize (shared with the Englishman F.G. Hopkins) in 1929 (Boomgaard 2006:205).

Christiaan Eijkman's results, published in the medical journal Geneeskundig Tijdschrift voor Nederlandsch-Indië in 1896, appeared to go against prevailing medical wisdom about the causes of disease. Diseases were contagious, arose from uncleanliness, or from 'miasmas', obnoxious if invisible vapours that escaped from the soil and made unsuspecting victims feverish, weak, bloated, or whatever the symptoms might be. Other creative explanations included bad air, enriched by a 'fermentation', or, where sleeping quarters were already well ventilated, the blame went to nocturnal drafts

1 The sources speak of 'afgewerkte' versus 'half afgewerkte' rice (or rice in 'zilvervlies') that is, white versus brown, and finally, unhusked rice. (Paddy is an English term; the Indonesian word for unhusked rice kernels that are separated from the stalk is gabah; sometimes gabah means the - inedible - husks themselves.) To avoid confusion of the processes and the terms of husking, pearling, and so on, this text retains the terms paddy-brown-white distinction as far as possible. White rice may in addition be polished to remove the residue of the other processes and make the grains more shiny, sometimes it is also coated. For an exhaustive treatment of traditional methods of preparing rice, see Abé 2007, on terminology, pp. 32-37 and 50-89, while a summary of industrial methods is on pp. 74-5. Abé (2007:89) believes the common English appellation 'husk' is not technically correct but that the outer skin should be called 'hull'. Carpenter (2000:17-23) also details traditional and industrial treatment of rice. 
under tropical conditions. By Eijkman's time, however, progressive scientists believed that diseases were spread by microscopic germs, passed from person to person or through other channels.

In fact, Eijkman himself took years to recognize that the mysterious ingredient in brown rice was not a protection against some kind of poisonous toxin or infectious agent, but an essential dietary component, the lack of which could cause severe nerve damage and even death. Today, this substance has the name of vitamin B1 or thiamin, while beriberi is one of the well-known if relatively rare vitamin deficiencies. A whole field of nutritional science has since arisen.

Eijkman's discoveries took a long time to gain widespread acceptance in the medical world, at times he himself doubted the consequences of his research. Convinced that a disease must be of infectious origin, he himself even criticized others who adhered to the 'food deficiency' theory of the disease. ${ }^{2}$

Only after further research, much of it in the Netherlands Indies, did most scientists - Eijkman included - accept that beriberi was a nutritional deficiency. Prevailing ideas about hygiene, contagion, and the spread and prevention of disease had stubbornly stood in the way of comprehending what was happening to the victims and why. Finally, some scientists closed the discussion by

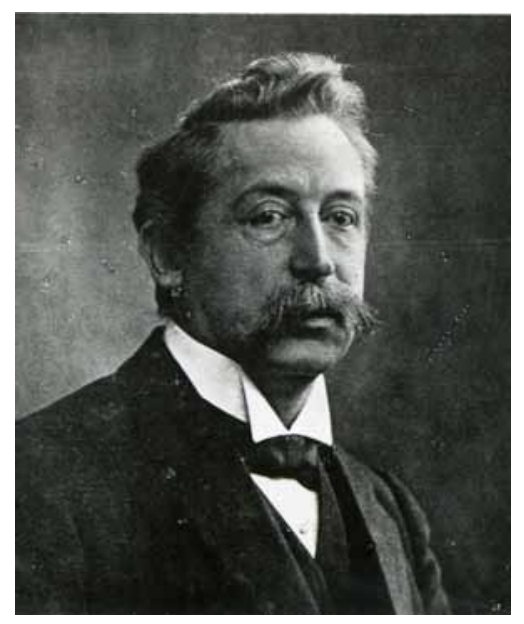

Figure 1. C. Eijkman, circa 1900

2 Carpenter 2000:55. See also Eijkman's Nobel Prize acceptance statement, reprinted in Jansen 1957:168-78. 
isolating crystalline thiamin, which is easily destroyed by the usual methods of searching for it, making it available for treatment. In the 1920s and 1930s, others determined its chemical composition, unlocked the mechanism of the disease itself, and found the prophylactic dosage necessary for humans (Carpenter 2000:108-15). For years, however, ideas of cleanliness or contagion turned out to be enemies of appropriate treatment for the victims.

Not a new or unknown disease, beriberi appeared to be reaching epidemic proportions in certain parts of the world in the late nineteenth century. This chapter sketches the experience of beriberi between the 1850s and 1914 in the Netherlands Indies and especially on the tin-mining island of Bangka (then spelled Banka), where the disease among the Chinese mine coolies was a serious, even deadly, and stubborn problem. Here and elsewhere, officials and medical specialists were pressed to take measures against the disease - measures that for decades were exercises in futility.

BERIBERI IN HISTORY: A GLOBAL DISEASE

Known from observation for centuries and in a number of different lands, beriberi acquired a variety of names, but descriptions of the symptoms show the disease was the same. In many lands, it appeared seasonally, as for example in Japan, where it tended to show up in the wetter, hot months of July and August, only to disappear again toward October, and where it was called kakke, a name derived from the Chinese.

For the most part (Japan is an exception), it was a disease of the tropics. It affected mostly, although not exclusively, rice-eaters. Some authors think it showed up among Roman armies on their expeditions to the Near East, and the Chinese described it centuries ago. A German employee of the Verenigde Oost-Indische Compagnie (VOC, East India Company), Albrecht Herport, on his way to the East Indies in the mid-seventeenth century, reports how, when bad weather buffeted the ship, they had "many sick men [...] many suffered from barbieri (this is a paralysis of the extremities) '. ${ }^{3}$ Once ashore, these victims usually recovered - or fell prey to another disease.

Bontius was among the first to describe the symptoms of beriberi in the Netherlands Indies. Early Portuguese missionaries in

3 'viel kranck Volck..., etliche lagen an der Barbieri, (ist ein Erlamung an den Gliederen)' (Herport 1930:34-5). 
Ambon in the sixteenth century also suffered from it. ${ }^{4}$ No one was really sure what the cause might be, but if the illness was not too severe, the symptoms would disappear by themselves, especially if the victim got rest and better food. ${ }^{5}$ The Japanese often dealt with seasonal beriberi by adding small red adzuki beans to their diet - legumes are an excellent source of the vitamin, as later came to light. On the other hand, sometimes victims continued to have problems long after the disease retreated, and it might leave them susceptible to other illnesses. ${ }^{6}$ Only if the paralysis had become so severe that it affected vital organs like the lungs and heart was death the inevitable outcome.

\section{NEW PROBLEMS IN THE NINETEENTH GENTURY}

In the late nineteenth century, beriberi was becoming both more common and much more deadly. Suddenly, the disease would appear in a group of people, often young men, often immigrants, and, for some reason, often the most strapping individuals, who would seem to be the picture of health, good nutrition, and immunity to disease. The 'epidemic' appeared selectively: natives of a place were seldom affected. Common along the seacoast, it was rare in the interior. At first, Europeans were seldom victims and observers speculated that this was a disease of Asians. The sickness also appeared to be an urban phenomenon, hovering around ships or certain buildings, such as prisons, barracks, hospitals, asylums, sometimes only in certain stories of a building. Wetness or dampness, overwork, and poor hygiene seemed to contribute, while exposure to other diseases might complicate the symptoms and make diagnosis difficult. Above all, beriberi had something to do with rice. ${ }^{7}$

In the Netherlands Indies in the second half of the nineteenth century, beriberi suddenly appeared among certain definable groups:

4 Carpenter 2000:24. For Valentijn's and Bontius's descriptions of beriberi, see Editor 1854. Interestingly, Bontius insists that 'it is not mortal of itself' unless muscles of the heart or thorax were affected (excerpted in Editor 1854:516).

5 Even earlier, at the dawn of the seventeenth century, Van Neck described beriberi: 'Deese siecte, na onx vermoeden, ontstont ons van de rijs, die wij doen wel 16 maenden lanck gegeten hadden, deur faute van broot' (This disease, in our opinion, appears from the rice we have been eating for sixteen months, for lack of bread) (Vierde schipvaart 1980:231-2). The antidote was, if possible, to land and get fresh fruits and meat.

6 For example Scheube (1896:163), 'Der häufigste Ausgang der Beriberi ist die Genesung' (The most frequent outcome of beriberi is recovery).

7 Scheube (1896:140-1) gives a contemporary medical view of the etiology and spread of the disease. 
prisoners, coolies in the tin mines or in plantations, those on board ships (especially the native personnel), inhabitants of certain institutions like hospitals or orphanages, and finally, the army. Clearly, it was on the increase, both in frequency and severity. But why?

The connection with institutions meant that persons for whose well-being the government was ultimately responsible - not just criminals - were suffering. The search for explanations became more urgent after 1870 when large numbers of soldiers fighting in the Aceh wars succumbed. There, first natives, then Europeans sickened, refuting the theory that Europeans might be 'immune' to the disease. By 1884, at the latest, the search for the cause and appropriate treatment had become urgent.

Meanwhile, in 1883, beriberi in the newly-formed Japanese Imperial Navy was sending sailors to the hospitals in droves. Neither the weather nor unsanitary, crowded conditions aboard ship seemed to be the problem. Naval doctor Kanehiro Takaki noticed that the food given the sailors was wanting in protein (which he measured as 'nitrogen'). After a particularly disastrous outbreak of sickness aboard a training vessel in 1883, he convinced authorities to change the food supply in the following year, adding meat, condensed milk, bread, and vegetables to the diet, while correspondingly reducing the rice intake. In contrast to the previous year's voyage, on that of 1884 there were no deaths and only fourteen sick, all of them men who had refused to eat their allotments of meat and milk (a hint that dietary habits would complicate treatment). The successful experiment led to a general change in the sailors' diet. By 1886 there were no more deaths and only three cases of the disease in the entire Imperial Navy. Takaki's case rested, he received baronial honours, but his colleagues did not believe his conclusions (Carpenter 2000:10-3).

Even earlier, in 1873, a Dutch naval surgeon named Van Leent had equally good results with Javanese naval personnel serving on the run to Aceh. When up to 60 per cent of them came down with beriberi while at sea, he determined that they should get the same diet as the Dutch sailors (few of whom caught the disease). Sickness rates dropped steeply. ${ }^{8}$ However correct this treatment might have been, how could he convince Javanese to eat pea soup, sausages, and cheese? ${ }^{9}$

8 Van Leent, cited in Carpenter 2000:12-3. See Leent 1880.

9 Eijkman, cited in Jansen 1959:170-1. Some did resist the change in food; Takaki's subjects were also averse to meat, milk, and bread. Cultural resistance to dietary change remained a problem and probably torpedoed some well-intentioned efforts. As is known today, many Asians also do not tolerate milk. 
Both these doctors published their results, Takaki in Englishlanguage journals, Van Leent in the flagship of the Netherlands Indies' health services, the Geneeskundig Tijdschrift voor NederlandschIndië. Nevertheless, many colleagues pooh-poohed their results - or failed to read them for reason of language. ${ }^{10}$

If the altered diet was unattractive to Asians, a worse alternative was for the victim to fall into the hands of Western and Western-trained doctors. Medications and treatments a state-of-the-art medical text of 1896 proposed to 'help' the unfortunate sufferer included: various laxatives or purgatives, calomel, digitalis, bloodletting, morphine, arsenic, iron, belladonna, quinine, a syrup combining 'strychnine, phosphoric acid, sodium sulfate, sulfate of iron oxide and quinine sulfate', and electric shocks for damaged nerves (Scheube 1894:202-3, 1896:170). External applications were rubdowns with eucalyptus or capsicum and cold showers. As late as the mid-nineteenth century, one doctor recommended drawing blood, using leeches, or moxibustion, ${ }^{11}$ which later fell from favour. Luckily, the victim might get extra fruits, meat, and port or red wine, for prevalent opinions still agreed that rest and good food were helpful. Unfortunately, most caregivers often failed to apply this wisdom, continuing to deny the importance of diet as a preventive.

On a lighter note, when beriberi appeared at a Protestant seminary for native missionaries in Depok in the 1880s, investigators claimed that lodgings and food were excellent and the young men had plenty of fresh air. Therefore, they prescribed each student a large glass of milk laced with brandy and sugar a few times daily, a treatment that promised to be popular but that was unfortunately not tried elsewhere. ${ }^{12}$ Often, better food and rest did help but usually only slowly, and the sickest died in spite of the interventions (Scheube 1894:204).

Why some treatments succeeded was still a mystery. Apart from solutions like those of Takaki and Van Leent, nineteenth-century medical men's wisdom failed stubbornly. Demographic epidemiology seemed to lead nowhere. Each time a population was identi-

10 Carpenter (2000:10-3) points out that the Japanese Navy employed English-trained medical men, but the Imperial Army relied on Germans and German-trained doctors, and Army specialists dismissed the experience of the sister service. The Japanese Army nearly had to withdraw during the Russo-Japanese War (1904-1905) because over 90,000 men fell seriously ill with beriberi (Carpenter 2000:88-9). The navy had no problems.

11 Lindman 1854:156-7. Moxibustion, from Chinese traditional medicine and related to acupuncture, has been known in the West since the seventeenth century. It consists of burning small amounts of medicinal herbs above or on certain points of the body.

12 Berg 1886:65-6. Cow's milk is a good source of vitamin B1. 
fied as especially susceptible to beriberi, other groups in different environments fell prey to the disease. On the other hand, if it was a miasma from the earthen floors of the sleeping quarters, why were dwellings with proper wooden floors affected? Rain and cold weather seemed to promote the disease, but in some places it was most severe in the hot, dry season.

\section{CLEANLINESS VERSUS DIET}

Not for nothing has the nineteenth century (in fact the second half of it) been called the 'Century of Hygiene'. Spurred by discoveries in bacteriology and contagiousness of diseases, many scientific minds focused solely on identifying the agent responsible for the spread of what they still presumed was an infectious disease.

Yet during these same decades, signs multiplied that beriberi was not a contagious disease and not caused by some kind of germ, mould, toxin, parasite, or bacillus (Scheube 1894:205). Scurvy was, of course, long known as a disease of sailors; since the eighteenth century adding certain foods to ships' provisions had met the challenge, even before the relevant vitamin $(\mathrm{C})$ was discovered. As mentioned, fresh meat, fruit, and vegetables were also an early treatment for beriberi. Because of their preference for 'scientific' explanations, however, too many researchers refused to believe that changes in diet might be the answer.

What had worsened the nutritional situation and stood behind the 'epidemic,' was the introduction of the industrial milling, pearling, and polishing of rice in major centres in the late nineteenth century, such as Bangkok, Saigon, or Rangoon, and also in Java. However, it was not a one-to-one situation, as will be seen.

Unhusked rice (paddy) can keep well if it is dry and protected from vermin, as villagers all over Asia knew. Shortly before cooking it, they pounded and winnowed the grain by hand. Occasionally, they harnessed water or animal power to the task. This method, although removing both the husk and the bran (in a single process), did so imperfectly, thus retaining much of the food value in the germ and the layers surrounding the rice kernel. ${ }^{13}$ Spoilage was not a problem because peasants did not store this rice but prepared it just before consumption.

13 According to Abé (2007:53-8), traditional methods of handling rice remove only a fraction of the bran, even as little as 20 per cent. 
Exporting unhusked paddy was, because of its higher weight, not commercially desirable. Some exporters did export "cargo rice', that is rice with the husk but not the bran removed, which is called here 'brown rice'. Rangoon, the major supplier of the East Sumatra tobacco plantations and a supplier for Bangka in the twentieth century, shipped most of its export rice as 'cargo rice'. ${ }^{14}$ Husked rice, however, unless completely dried and otherwise protected, spoils easily if the bran is not thoroughly removed. Thus large grain exporters would usually remove as much of the bran as possible; in addition, white rice was simply more attractive to consumers. Apart from its unfamiliar taste and consistency, brown rice requires longer cooking time.

Before the industrial age, lots of human power, sometimes supplemented by simple machines, could produce very white rice with little or no bran. This was done in Japan as early as the eighteenth century, but the labour involved meant it was available only to the rich. ${ }^{15}$ Then, in the course of the nineteenth century, new machines came into play. In the southern United States (where rice was a commercial commodity, not a staple), ${ }^{16}$ steam-driven rice mills replaced hand mills, becoming common by the $1830 \mathrm{~s} .{ }^{17}$ Siam imported machinery for a steam-driven rice mill, probably its first, from the United States in 1858 (Terwiel 1983:184). By the end of the century major rice exporters, whether in Rangoon, Bangkok, or Saigon, were thoroughly mechanized.

Not the steam engine itself is to blame, it merely provided the power. After the paddy was husked, special cones removed the bran and outer layers of the grain in a process sometimes called 'pearling'. The rice might pass through as many as four cones (Latham 1998:22-5; Grist 1955:227-9, 248-9). As a result consumers eating machine-prepared white rice, which was typically polished after removal of the bran, were getting more or less pure starch. When cooks washed it thoroughly before cooking, a common practice among both Javanese and Chinese, especially when cooking for a group, then cooked it in plenty of water, pouring off the excess, they removed any residual vitamins.

Such de-vitaminized rice was the typical food of armies, ships' crews, inmates of various institutions, and coolie labourers - and later of urban populations. Not surprisingly, beriberi turned up

14 Private communication, Yoshio Abé.

15 This contributed to the pre-industrial prevalence of beriberi in Japan.

16 Private communication, Yoshio Abé.

17 www.er.nps.gov/nr/TwHP/wwwlps/lessons/3rice/visual4.htm (accessed 26-4-2007) (picture and description of a steam-driven mill in Georgetown County, South Carolina). 
among such diverse groups as the Philippine militia, orphans, prisoners, students at a Christian seminary near Batavia, coolies in Malaya and the Netherlands Indies, and even members of the Siamese police force who received rice allotments from the government. Furthermore, 'institutional' diets were usually deficient in other foods such as fresh vegetables, legumes, or meats that might make up for what the cooked rice now lacked.

Rural natives were largely 'immune', to beriberi, not because of some special genetic resistance, but because, in addition to some vegetables and side dishes, they were still consuming hand-milled rice, or rice milled by simple mechanical devices, which retained the beneficial parts of the grains that the modern mills removed. The 'epidemic' of beriberi had been set loose by modern technology. ${ }^{18}$

\section{INTERNATIONAL FOCUS ON RICE}

Beriberi had become an international problem in the late nineteenth century, but national thinking limited the search for a solution. One attempt to 'globalize' the search for an answer came from the Americans in the twentieth century. Determined to be a model colonialist in the Philippines (against all odds), they soon faced 'outbreaks' of beriberi, in particular among the native militia, the Philippine Scouts. They took two steps: they changed the diet, after reading of similar steps taken by Dutch and British colonial officials, adding potatoes and bread in place of some of the rice (whether the Scouts were happy about this is not recorded), and they invited neighbouring countries to a conference in 1910.

Thumbing his nose at his countryman Takaki's work, the Japanese delegate still blamed a microorganism, while some other participants held out for parasites or toxicity. In the end though, the majority of those present supported a resolution that blamed beriberi on "continuous consumption of white (polished) rice as the staple article of diet...'. ${ }^{19}$ This result should have been authoritative, but what was to be done in the Netherlands Indies?

18 In Japan, the white rice preferred by urban populations could be achieved by aggressive hand-milling. In addition, particularly during the hot summer, many people favoured a 'cooling' diet of little more than rice and tea. Apparently, Japan's rural people often sold their rice, a higher-priced commodity, and themselves consumed more barley and wheat (both of which are well provided with the appropriate vitamin). See Carpenter 2000:8-9. Alternatively, they did not pound rice so thoroughly for their own consumption.

19 Carpenter 2000:80-3. Americans often call white rice 'polished' rice to distinguish it from the 'brown' variety. Polishing was an additional process, following removal of the bran by pearling. 
BERIBERI IN THE NETHERLANDS INDIES

The Netherlands Indies government bought much of its rice, often through local ethnic Chinese dealers, from mainland Southeast Asian exporters (sometimes via Singapore) or from centres in Java. This rice fed the Netherlands Indies army, navy, the tin miners (except those who purchased rice for themselves or were in nongovernment operations), prison inmates, and other institutional groups. Just such groups had become a 'laboratory' for ideas about hygiene, cleanliness, ventilation, and disinfection. ${ }^{20}$

In Batavia, the Geneeskundig Tijdschrift voor Nederlandsch-Indië, founded under a slightly different title in 1851, devoted more articles to the question of beriberi than to any other topic during its first three decades of publishing. Eijkman's contribution of 1896, about polished rice was just one of many submissions that purported to explain this mysterious, explosively appearing 'epidemic'. Other authors, often armchair 'experts', continued to challenge the experiences of a Van Leent, Takaki, or Eijkman.

A review of the index to the Geneeskundig Tijdschrift voor Nederlandsch-Indie gives some idea of the geographic and demographic distribution of the sickness and offers an insight into how prevailing ideas about contagion and hygiene stood in the way of confronting the evidence. Observers who had experience with a single group of sufferers only or other authors who were grinding their own axes sent most of the contributions. One problem was that they may even have been dealing with health problems that were not, or not exclusively, beriberi, for correct diagnosis was often difficult. The major proponents were those supporting the idea of either infection, poisoning, or deficient food. ${ }^{21}$ The idea of infection was probably the most persistent, although beriberi repeatedly proved to be non-contagious. This in turn gave rise to multiple suggestions for prevention.

The second group favoured some kind of poisoning from the grain itself, analogous to the example of ergotism, which was caused by a fungus that grows on rye. The toxins cause severe nerve damage (especially in the limbs) and hallucinations. At the time, pellagra, too, was thought to be from a poison in maize, although it was later shown to be a deficiency disease. ${ }^{22}$ Some suggested the

20 Corbin 1982:123. I thank Kees van Dijk for this reference to miasmas and the battle against them.

21 As emphasized in Langen 1927:5-7.

22 Ergotism has been known since at least the sixteenth century; a fungus on rye produces oversized 'kernels' of rye called mothercorn, which contain the toxin ergotamine (Dieren 1887:7-9). Modern mills remove these. Pellagra, a deficiency disease, spread with the introduction of maize as a staple grain in the eighteenth century; it comes from a deficiency of vitamin B3 (niacin) in, for example, a one-sided diet of (untreated) maize or other grain. For a time, it was also attributed to a toxin in maize (as in Dieren 1897). 
agent was in spoiled fish, since salted fish was a regular item in coolie and other diets. The idea of a nebulous but poisonous 'miasma', rising from the soil, also died hard. After all, in beriberi, the feet were affected first (Scheube 1896:142).

When deficiency returned again and again as a probable cause, some contributors countered that many victims were not only physically sound, but ate hearty, apparently nutritious meals. Furthermore, among any given population eating the same diet, some sickened and others did not.

The outbreak among soldiers in the Aceh War after 1870 made it a military necessity to explain and eliminate the disease. Beriberi cases among Europeans in the Netherlands Indies army climbed from 2411 in 1878 to 5338 in 1884, while at the same time, the number of those sick with malaria, although higher, was retreating $(44,552$ in $1878,19,501$ in 1884). The statistics for 1885-1908 show that beriberi rates then declined from about 40 per cent of all native troops and 24 per cent of Europeans to less than 10 per cent from 1898 onward (Wijckerheld Bisdom 1911). Since the deficiency theory was not accepted at this time, what produced the good results? The men were ordered to disinfect their quarters and clothing after 1886 (see below for this treatment), and, more usefully, the diet was improved to include more protein and fat. ${ }^{23}$ The end of the 'concentrated line' of defence in Aceh probably helped. Greater mobility after the lifting of the line may have given soldiers access to native rice and a better variety of fresh foods. Another possibility is a change in the rice supplier. ${ }^{24}$ Whatever the reason, the apparent benefits to Aceh's military did not yet help other groups - a health problem in the army, and that in wartime, was far more serious than one among coolies or prisoners.

\section{NEW RESEARCH}

By the 1880s the idea of improving nutrition had again receded into the background (Donath and Veen 1945:75-6) as was evident in 1884 when the government appointed a commission which included Eijkman and two scientists from Utrecht, C.A. Pekelharing (a pathologist) and C. Winkler (a neurologist), to investigate the situation. Having no time for experiments, the prestigious doctors

23 Dieren 1897:94. These foods incidentally contained more vitamin B1.

24 From the end of 1888, rice provisions came from the Pamanukan-Ciasem area of West Java (Gelpke 1890:147). The 'concentrated line' was a kind of 'clear and hold' defence line behind which the Dutch forces were actually confined. 
resorted to a theory of infection well-suited to the superficial experience of beriberi as an 'epidemic'. In his preliminary report of 1888, Pekelharing insisted that he had isolated an infectious agent from the blood of patients and from the air (or rather the walls) of the quarters where they lived. Agreeing that the disease was not contagious, he identified the real culprit as 'vuil' - filth. The earthen floors of living quarters should be well-drained and after becoming wet, they should be cleaned and disinfected, and kept dry (although he also noted that the supposed infectious agents he had collected were resistant to dryness). Clothing and quarters should also be disinfected. This disease spread not through contaminated food but through inhalation (Pekelharing 1888). His recommendations - disinfect the living quarters - dominated the following attempts to rein in the disease (including those in Aceh) ${ }^{25}$

Actually, Pekelharing was at the cutting edge of medical science with his 'micrococci'. The germ theory of disease was in its infancy, finally displacing the pre- Pasteurian ideas of 'miasma' and bad air (although some writers clung to the miasma hypothesis as late as

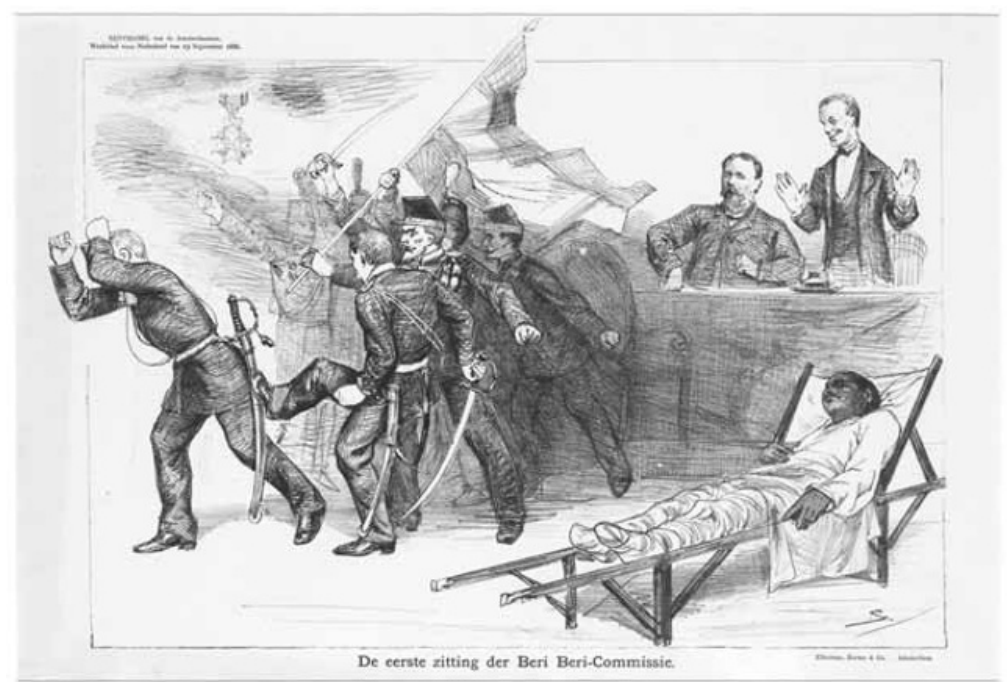

Figure 2. Commission on beriberi (De Amsterdammer, 23-9-1888)

25 Nationaal Archief (NA), The Hague, Ministerie van Koloniën (Koloniën), 1850-1900, nummer toegang 2.10.02, inventarisnummer (inv. nr) 6480, Mailrapport (MR) 1890, 433+. 
1890).$^{26}$ In the 1850 s, the riddle of the cholera epidemic in London had been solved without looking for microbes. ${ }^{27}$ In the 1880 s, however, men like Louis Pasteur, Robert Koch, and others were developing the theory of infectious diseases and isolating the bacterial agents that caused these infections. But Pekelharing, however upto-date, was mistaken.

Fortunately, Eijkman, who had been sent to Bangka in $1888,{ }^{28}$ remained in the Netherlands Indies and continued investigations by experimenting with animals. In 1896, he correctly pointed to highly-milled white rice as a cause of (or in his initial opinion a contributor to) beriberi, depending on how thoroughly it was milled, and how carefully it was cooked. Although Eijkman had put his finger on the crucial factor, he first thought that white rice either contained a toxin (like ergotamine) or somehow lacked the antidote to whatever external infectious or toxic agent was causing beriberi. By 1898, however, he recommended that prisoners be fed brown rice. Subsequent research had convinced him.

Following Eijkman, his successor G. Grijns ruled out decisively the idea of a toxin in rice and brought the research much farther, also suggesting the value of legumes in preventing beriberi. In 1897, A. Vorderman had demonstrated the value of brown rice when he undertook a statistical analysis of prisoners in Java, with data gathered from visiting all of Java's 101 prisons, consulting medical data from some 250,000 inmates. His results showed that beriberi was 300 times more common where prisoners consumed white rice than where brown rice was the rule. Such results would seem conclusive, but his study attracted little positive resonance. ${ }^{29}$ Finally, D.J. Hulshoff Pol experimented with feeding mung beans to inmates of a mental hospital in Bogor. He published his results, which showed both the preventive and curative power of the beans, in 1902 and 1904. ${ }^{30}$ Legumes would later prove to be an important part of anti-beriberi diets.

26 A recent article about Siam distinguishes between 'pre-Pasteurian' and 'Pasteurian' medicine, the former involving 'miasmas,' the latter, 'germs' and contagion (Davisakd Puaksom 2007). 27 In London, demographic epidemiology - isolating the source by seeing where victims lived and then, in this case, finding most victims used a single well for drinking water - did the trick (Johnson 2006). Only later did researchers identify the microbes, long after closing the well ended the epidemic.

28 NA, Koloniën, 1850-1900, 2.10.02, inv. nr 6469, MR 1888, 519+.

29 The Vordermann study is discussed in Carpenter 2002:46-51. Most of the rice was neither completely 'brown' nor completely 'white' and Vordermann distinguished, by analysing samples, between 'mostly brown', 'mixed', and 'mostly white'. Many prisoners were only incarcerated for a few days and had no time to get sick. In 'mostly white' prisons, however, up to one-fourth of long-term inmates developed the disease.

30 Carpenter 2000:52-63; Donath and Van Veen 1945:76-7. Hulshoff Pol himself also clung to the infection theory for a time. 
Modern observers might easily challenge the many misguided theories of the disease, but beriberi researchers were treading new territory. The presence of very severe, even deadly forms of the disease made the traditional solutions of 'better food' or 'strong food' (as ancient Chinese texts proposed) insufficient. Differences in susceptibility to beriberi among individuals complicated the search. Certain factors like the need to perform hard physical labour or the presence of fevers, for example from malaria, raised the body's nutritional requirements and thus contributed to deficiencies. This also partly explains why outbreaks did not affect all persons in a group, and also why often the most physically 'healthy' young men seemed to be the earliest affected.

This brief account simplifies the arguments and counterarguments, as well as the achievements, greatly profiting from the wisdom of hindsight. Nonetheless, the failure to implement promptly what knowledge was available to change the fate of the seriously, often mortally, ill deserves criticism.

\section{BERIBERI ON BANGKA}

From the first reports about the disease in the 1850s to the radical improvement in the 1910s, decades of helplessness and futility nagged officials on this little island, but the disease itself plagued the workers. Most of the tin workers, the so-called coolies, were Chinese, usually immigrants. If the story of the scientists' search seems in retrospect like a success story - albeit with a fair amount of infighting - the situation on the ground was a decades-long tragedy.

Bangka was an ideal place to give support to either the 'miasma' or the 'infection' theory of beriberi. A visitor to the mines in the 1880s saw things this way:

The mine buildings look alike everywhere [...] four buildings at right angles to one another, which form, in the middle, a wide inner court. The front building, made of planks [...] contains a row of benches and tables; here the labourers [...] take their meals [...]. The two side buildings serve partly as kitchen, partly as sleeping quarters for the unmarried workers [...]. These living quarters make a poor impression. In most cases, they are old, neglected buildings, scarcely ever repaired, and where cleanliness would be sought in vain. The sleeping areas in particular are quite dirty. (Posewitz 1886:99.) 
The miners lived in neglected housing, surrounded by vuil. Their work required them to stand in water for long periods, the upper body exposed to the sun, hardly health-promoting. ${ }^{31}$ New arrivals ( sinkeh) frequently joined the mines - usually once a year and they were more susceptible to the disease than local-born Chinese, called peranakan, which made officials suspect that sinkeh might be introducing the disease from China or Singapore. Other diseases, malaria, syphilis, influenza, and so on, produced symptoms that both contributed to the outbreak and confused the diagnosis (Langen 1927:76-85).

Not surprisingly, the first report in the Geneeskundig Tijdschrift voor Nederlandsch-Indië on beriberi, observed in 1853, was from Bangka. A medical officer reported the presence of some twenty patients in the hospital of Mentok, most of them Europeans or natives, not Chinese coolies. He ascribed the sickness to mysterious 'cosmic-telluric influences, unknown up to now' ${ }^{32}$ Previous accounts had blamed cold weather, rain, bad food, bad water, a polluted atmosphere but none of this seemed to fit the cases in Bangka. Perhaps it was really a miasma. ${ }^{33}$ In February of the following year, official reports noted several cases among workers in the district of Toboali, sixteen sickened and three died. General malnutrition may have been to blame, for by August, when the government supplied extra rice, salt and oil to meet the crisis, cases vanished..$^{34}$ Thus, the disease began as a sporadic occurrence, not confined to the mines, but within a few decades, it was a major problem on that island and concentrated among the coolie labourers.

\section{ORGANIZATION OF TIN MINING AND COOLIE WELFARE}

The appearance of the sickness on Bangka may have been partly the result of changes in the structure of the mining operations themselves. True, Bangka had been dependent on imported rice ever since outside labourers came from China to work the mines in

31 Kappen 1860:515. Interestingly, this author already insisted that 'well-fed individuals are not affected by beri-beri' (Kappen 1860:511), while others insisted that nutrition of all the men was adequate. Standing in water gave rise to arthritic complaints, but not beriberi.

32 Since 'cosmic' means extra-terrestrial, and 'telluric' means terrestrial, from earth, this would certainly cover a wide array of possible causes.

33 Lindman 1854:132, 150. Lindman noted that he also experienced an 'epidemic' of beriberi in Probolinggo in 1849 and thought the lack of information in the medical literature was because the disease had been relatively unknown before then. As noted, descriptions of the disease existed from the seventeenth century or earlier.

34 Arsip Nasional Republik Indonesia (ANRI), Jakarta, Bangka 3B/7, General Report 1854. 
the mid-eighteenth century, if not earlier. The island's yearly rice production, mostly from dry-field ladang, barely sufficed for the native rural population, and occasionally even they had to import rice to make up a shortfall after a bad harvest.

When tin-mining by groups of Chinese labourers began in the eighteenth century, the ruler of Bangka, the Sultan of Palembang, exchanged rice and other necessities for the tin produced. When first the British, then the Dutch, took over the island directly in the early nineteenth century, the system of food advances and tin purchases remained largely the same, only the administrators changed.

Under the British and Dutch, initially, work gangs of miners organized in cooperative kongsis (benevolent associations of overseas Chinese) mined and smelted the tin. The workers chose a headman from among them, following their own bosses, while each had a share in the work and the profit. The kongsis purchased rice and cooking oil on credit from representatives of the government power. They were themselves responsible for other food, and most early kongsis had a garden and pigsty of their own, perhaps purchasing salted fish from local fishermen.

From about the middle of the nineteenth century, the situation of coolies appears to have deteriorated. The mine-working kongsis became mere sub-contractors as the government extended control over the operation of the mines. At the same time, the old system of shareholding was retreating. More and more, workers in the mines were not shareholders, and shareholders were not workers but tradesmen and townsmen who invested by purchasing arriving coolies and selling them as labourers to the mines. ${ }^{35}$ Little incentive remained for the kongsi headmen to consider the interests of workers who were no longer his co-owners (Diest 1865:21). The kongsis still existed, but they were no longer autonomous, being under the ultimate direction of government-employed mine engineers, whose instructions, after 1880, they had to follow (Jaarverslag Bankatinwinning 1912:xlii).

The (Chinese) mine headmen did not need to fear the workers, for the government was on the side of the headmen in any dispute. Probably, care for the food of the workers receded proportionately. By 1880, non-shareholders - coolies - outnumbered shareholders in the mines and the relationship continued to change in favour of non-shareholders (Koloniaal verslag 1880:200). These, however, were facilitating conditions, not the cause of beriberi outbreaks.

Another change occurred in 1884, when the government stopped delivering rice and instead offered the mines a cash

This change was noted - and lamented - as early as 1853 (Koloniaal verslag 1853:168). 
advance equivalent to the purchasing price of the rice (Jaarverslag Bankatinwinning 1912:xlv). The coolies themselves only saw cash at the end of the mine year, when the tin was smelted and sold. During the year they depended on the mine headman for food and other supplies. Only in 1902 did they begin to get small monthly cash advances to buy supplementary food or other items (Jaarverslag Bankatinwinning 1912:liii). For much of this time, the coolies received inadequate diets for men performing hard labour, and complaints mounted as sometimes the rice itself was hardly edible because of improper storage.

\section{SYMPTOMS AND SUGGESTIONS}

Statistics on morbidity and mortality of tin miners on Bangka attributed to beriberi - although incomplete and defective - illustrate the seriousness of the challenge in the mines. European overseers were not constantly present in the mines and many cases may have gone unnoticed. Diagnosis, as noted, was often difficult.

Table 1. Reported cases of beriberi and deaths, Bangka

\begin{tabular}{|c|c|c|c|}
\hline Year $^{36}$ & Number of sick & $\begin{array}{c}\text { Deaths } \\
\text { attributed to } \\
\text { beriberi }\end{array}$ & $\begin{array}{c}\text { Total number } \\
\text { of workers }\end{array}$ \\
\hline 1854 & 16 & 37 & 184 \\
1860 & some (Merawang) & 37 & 7,296 \\
1863 & large number (Merawang, Pang- & - & 7,402 \\
1865 & kal Pinang, Sungaiselan) & & 7,288 \\
1869 & reported among military & - & 7,506 \\
1871 & 'many' (several districts) & - & 7,391 \\
1872 & 'less' & - & 7,964 \\
1881 & 'many cases' (Mentok) & - & 7,588 \\
1882 & 'a few', Chinese and native & (Mentok) & 7,525 \\
1883 & some (Marawang, Sungaiselan); & - & 7,195 \\
& $30 \%$ of miners in Sungailiat & &
\end{tabular}

36 As an indication, the table gives available statistics on numbers of sick. Note that not all years are included.

37 Number of miners varied during the year. Later numbers represent an average. 


\begin{tabular}{|c|c|c|c|}
\hline 1884 & various cases (four districts) & - & 7,195 \\
\hline 1886 & 'sporadic' & - & $\mathrm{n} / \mathrm{a}$ \\
\hline 1887 & 'a few' & - & $\mathrm{n} / \mathrm{a}$ \\
\hline 1888 & 539 & 105 & $\mathrm{n} / \mathrm{a}$ \\
\hline 1889 & $\begin{array}{l}\text { previous victims recovered, but } \\
\text { some new cases }\end{array}$ & - & $\mathrm{n} / \mathrm{a}$ \\
\hline 1890 & 'many' (Mentok) & - & 8,818 \\
\hline 1893 & 'rare' & $500^{38}$ & 8,860 \\
\hline 1894 & 800 (circa) & 342 & 12,345 \\
\hline 1895 & 169 evacuated $^{39}$ & 600 (circa) & $\mathrm{n} / \mathrm{a}$ \\
\hline 1896 & 591 evacuated $^{40}$ & - & 10,349 \\
\hline 1897 & 709 evacuated $^{41}$ & 123 & 11,310 \\
\hline 1898 & 319 evacuated & 107 & 13,083 \\
\hline 1899 & 158 evacuated & - & $\mathrm{n} / \mathrm{a}$ \\
\hline 1900 & 186 evacuated & - & $\mathrm{n} / \mathrm{a}$ \\
\hline 1901 & 329 evacuated & - & $\mathrm{n} / \mathrm{a}$ \\
\hline 1902 & 346 evacuated & almost 100 & 13,205 \\
\hline 1903 & 525 evacuated $^{42}$ & 210 & 14,229 \\
\hline 1910 & 1260 & - & 19,823 \\
\hline 1911 & 823 & - & 21,292 \\
\hline 1912 & 800 (circa) & - & 22,296 \\
\hline 1913 & 639 & 12 & 21,436 \\
\hline 1914 & 26 & - & 21,406 \\
\hline 1915 & 0 & - & 19,050 \\
\hline
\end{tabular}

[Numbers include shareholders, paid laborers, charcoal-burners for the smelters, and workers in privately-operating mines. Source: Koloniaal verslag, various years; Jaarverslag Bankatinwinning 1912, 1913, 1914; General Reports, Political Reports, various years]

38 This figure obviously contradicts the idea that beriberi was 'rare'.

39 To China. Others who were sicker were sent to Bogor for treatment and rest and then to China.

40 Probably to Bogor. Previously, the sick had been sent to Singapore or China and discharged there.

41 According to NA, Koloniën, Openbaar Verbaal, 1901-1952, 2.10.36.04, inv. nr 214, V 1-121903 , no. 38 , the number was 449 . This is the source of the following numbers of evacuees.

42 These were evacuated between 1 January and 28 March. Koloniaal verslag 1903 says only 388 were evacuated. 
Until the 1890s, the number of workers was about 7,000-8,000 and rose slowly in that decade to 10,000-13,000. After $1903(14,000)$, the number climbed to reach 20,000 during the 1910s. In bad years, the number of sick was 5-6 per cent of the force, but the number in an individual mine or mine district could be much higher.

Apart from collecting numbers, how did the colonial authorities treat the disease and what preventive measures did they take? The Chinese were expected to care for the sick in the mines, but they had little incentive to do so, especially if they thought the disease was contagious, as they apparently feared was the case with beriberi. Reportedly, they isolated the victims, perhaps in a small hut away from the mine, gave them a bit of rice and water, and left them to die. After a few days, if the provisions had disappeared, they added more, but did not, for fear of contagion, remain to see how patients were faring. ${ }^{43}$ In any case, the number of coolies with beriberi soon overwhelmed any residual ability of the mine kongsis to care for them. In some mines, one-third or even more of the labourers were sick, so that the mine authorities finally had to take general measures.

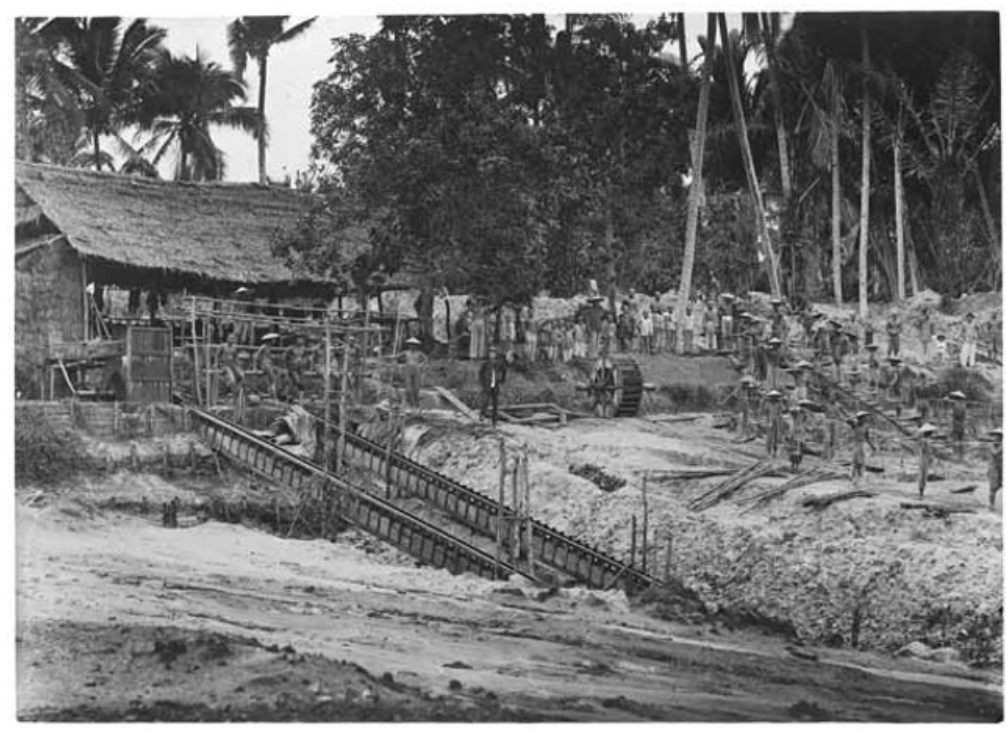

Figure 3. Chinese tin miners on Banka, circa 1920 (KITLV 34679)

43 Jaarverslag Bankatinwinning 1912:liv; Kappen 1869:513. This may be a legend, for it was repeated from account to account. 
Still officials mostly wrung their hands. The tiny Chinese hospital on the island cared for only 29 sick and infirm persons in 1852; it became totally inadequate for the dozens, even hundreds of sick. ${ }^{44}$ As numbers increased, leaving the mines to look after the sick became problematic.

The first cases, relatively few, appeared to be seasonal. As late as 1883, the sickness was said to have retreated toward the end of the year, but in 1884 it returned in Mentok, Jebus, and Sungaiselan. Five cases also appeared in Pangkal Pinang between March and September. ${ }^{45}$ Five cases also appeared in Pangkal Pinang between March and September. Mines with high proportions of sinkehs, that is, recent arrivals (who were never shareholders) also had the largest number of victims. On the other hand, in Jebus, where as a rule the miners were local-born Chinese peranakan, who often did not live on the mine premises, beriberi appeared to be comparatively rare.

\section{BELITUNG}

While in Bangka the question occupied engineers and bureaucrats, in Belitung, then called Billiton, the second tin island of the Netherlands Indies and a home of private enterprise, the disease was running a dramatic course. Because Belitung's production there was in the hands of a largely privately-owned company, official sources have less information about conditions there. Tin mining only opened officially in 1852. The disease seems to have picked up rapidly after that, especially in the 1880 s, and it ended earlier than on Bangka. Seven hundred miners died of beriberi as early as February-March $1863 .{ }^{46} \mathrm{~A}$ mine specialist working in the interior in the following year reported that 63 per cent of the Chinese in his mine died, of unknown diseases, within a single month, while health conditions for the Europeans in the early years were equally disastrous (Heerklotz 1868:87-8). In 1888-1889 there were 550 cases of beriberi. In the following year, among 8,334 workers, there were 588 cases, of whom 41 died. Some 441 victims of beriberi were 'evacuated' to China. ${ }^{47}$ In 1908 , of 12,500 workers, 700 were

\footnotetext{
44 Koloniaal verslag 1852/53:54; ironically, the government stopped supporting the hospital, which had been financed by a tax on remittances to China, in 1854. ANRI, Bangka 3B/7, General Report 1854.

45 ANRI, Bangka 5/9, 5/10, General Reports 1883, 1884.

46 As noted, the diagnosis may have been wrong in some cases (Swaving 1871:4).

47 Koloniaal verslag 1890:14, 232. 'Evacuation' here was a euphemism for getting them out of sight, probably many died because the ships' food was as bad or worse than that in the mines and there was no help available when they reached Chinese ports. Official publications of the Billiton Company usually depict the miners as satisfied and healthy.
} 
sick. This was the turning point, for in the following year, 1909, of 13,600 miners, only four were sick (Van der Heijden 1918:57-8).

As in Bangka, immigration and beriberi seem to have been positively correlated, and recruitment of new workers rose dramatically after the 1880s. Typically, several hundred arrived yearly, and if there were shortfalls of rice production in southern China, many arrivals already showed early symptoms of the disease when they landed. ${ }^{48}$ Coolies certainly received inadequate food during their journey, by junk, to the South. ${ }^{49}$ The presence of beriberi in the Straits Settlements, which was a recruiting area for miners, also drew blame. Was the disease being imported? (Jennissen 1911:503, 507).

Like Bangka, Belitung went through stages of explanations and treatments. In the 1870 s (1874-1876 was an especially bad time), company employees fought beriberi with ventilation. In the $1880 \mathrm{~s}$, they still blamed miasmas and contagion and burned down old buildings, abandoning others. Because cleanliness seemed essential, chlorine and caustic soda disinfected remaining quarters. More positively, the authorities encouraged maintaining gardens and raising animals to improve the diet. By 1888, the mining company began to send less serious cases to Bogor in hopes of returning those recovered to the mines, but this answer proved to be too expensive and they soon dropped the policy. ${ }^{50}$

After dwindling between 1893 and 1903, the disease suddenly peaked in 1903-1904. Again, nearly 300 were evacuated, most of them sinkeh. Once more, bad conditions in southern China seemed to be invading Belitung. New coolies underwent health inspections in Hong Kong and Singapore so that the sick could no longer be hired or enter the island. Java rice, which had been blamed for the outbreak in 1903, was now supplanted by imported (mostly white) rice from Siam or Rangoon, but this was not the answer. Finally, in 1908, the officials decided to take the work of Eijkman and others seriously. All imports of white rice stopped. The mining company provided the mines with brown rice (beras merah) only. After that year, all cases of beriberi came from persons living outside the mines who still subsisted on 'wholly' whitened rice. ${ }^{51}$

48 The time spent aboard ship may have added to the problem.

49 Heerklotz (1868:49) visited a junk in the bay of Tanjung Pandan, Belitung, in 1864. He claims the coolies received rice and Spanish pepper twice daily but no other food, and many died en route. About half of those who made it could expect to die in the mines.

50 Jennissen 1911:504. Gelpke (1890:146), comments on the irony that the military stationed in Bogor often suffered from beriberi 'epidemics', while chain-gang prisoners (and later tin miners) were evacuated to the same place to recover from beriberi.

51 Jennissen 1911:507. Jennissen (1911:510-1) interestingly points out that in the Straits Settlements, Indians were largely free of beriberi, for they traditionally ate beras masak, parboiled rice, which was unacceptable to other Asians because of its taste. The success story of brown rice is also told in Gedenkboek 1927:166. 
BANGKA (FINALLY) COMES AROUND

Bangka underwent similar stages, but moving the authorities to act took years longer. In the end, the health situation began to affect the colonial pocketbook, where it hurt most. Tin production on Bangka had peaked in 1856 at over 100,000 piculs (a picul is about 62 kilograms) and then fell to about 80,000 for the next ten years, falling further to 69,000 in 1869 . In the 1870 s, it hovered around 65-70,000 piculs (Jaarverslag Bankatinwinning 1912:xxxviii, xli; Koloniaal verslag 1870:155). Other factors also depressed production, of course, but an official report in 1871 does ascribe the decline in tin production to beriberi in several districts, as well as to bad weather. In 1884, a combination of drought and beriberi seriously hindered production, some mines even closed down. ${ }^{52}$ Bad results recurred in the following year. ${ }^{53}$ With international demand for tin and local demand for labourers growing, such losses were unacceptable. The late-nineteenth-century transition to mechanization in the form of steam-driven water pumps, to keep the diggings free of flooding more efficiently, and of various other machines, actually increased the need for workers. In addition, thanks to better methods of exploration, more workers were needed to open new, promising sites or to exert the extra effort needed to exploit nearly played-out ones. ${ }^{54}$ In the late 1890 s and into the first years of the twentieth century, beriberi was a major contributor to the annual death rates of 2-3 per cent among the miners. The export of the sick to China, Singapore, and later Bogor, where many nevertheless died of the disease, probably made the death rate appear lower than it really was. ${ }^{55}$

'Evacuation' of sick miners continued partly because of the persistent belief - contradicting virtually all of the medical literature - that beriberi was somehow contagious. In late 1895, Bangka's highest official, its Resident, summed up the measures taken to combat or treat beriberi: in the district towns were houses for the sick, except in Merawang (which is close to Pangkal Pinang). Many of the sick, however, were being shipped out with six (Straits) dollars in pocket money to Singapore, where they could look for work and were - according to the rationale - better off than in China. (How they could seek work when they were weak, paralyzed, or con-

52 ANRI, Bangka 1/17 Political Report 1871; NA, Koloniën, 1850-1900, 2.10.02, inv. nr 6354, MR 1872 and inv. nr 6442, MR 1884.

53 NA, Koloniën, 1850-1900, 2.10.02, inv. nr 6450, MR 1885, 675.

54 On mechanization and labour demand, see Heidhues 1992:60-1.

55 Of those sent to Bogor, 5-6 per cent were said to have died. 
fused is not clear.) New regulations said they should be returned to China, but many did not wish to go there, at least not at once, because they hoped to find work in the Straits. There could be no question of keeping them in Bangka, where they would be a burden and besides they were - once more - 'contagious'. ${ }^{56}$

Meanwhile, the beriberi sanatorium in Bogor was now open to Bangka coolies. By 1894, as previously in Belitung, the sick who were well enough to travel were sent to Bogor to recover and then back to China. In 1903, however, trouble arose in Batavia, when coolies on their way to Bogor passed through busy areas of the city. The sight of the men, shuffling or being carried on ox-carts in various stages of helplessness from the harbour to the train station, caused a near-riot and a new solution was necessary. ${ }^{57}$

China was not a satisfactory destination either. The men hoped to return to China eventually, but not without cash. Furthermore, the East Sumatran tobacco plantations, which also hired coolies in China, feared that the image of the sick returnees dumped at the harbours was giving the Netherlands East Indies a bad name, impeding their own recruitment there. ${ }^{58}$ In view of the problems connected with evacuation, including resistance from the coolies, in 1911, the authorities determined to transfer all care for the sick to Mentok. Once recovered, the men could return to the mines or to China. ${ }^{59}$

Was the problem homemade or coming from abroad, sneaking in with the newly arriving sinkehs? In 1898, mine officials on Bangka stopped all recruitment in Singapore, partly from fear that they might 'import' beriberi from there. ${ }^{60}$ On the other hand, a few years later, Bangka's bad reputation led the Hong Kong authorities to close down coolie recruitment there, reopening it only in 1907 (Jaarverslag Bankatinwinning 1912:1i), and the island continued to enjoy a terrible reputation among potential recruits in China.

Since evacuation was no answer, preventive measures were necessary, but as long as the cause of the disease was a mystery, what measures were appropriate? The results of the Pekelharing mission soon reached the island. In 1884, a governing official took

56 Letter of Resident of Bangka, 25-11-1895, in: NA, Koloniën, 1850-1900, 2.10.02, inv. nr 6516, MR 1896, 8.

57 NA, Koloniën, Openbaar Verbaal, 1901-1952, 2.10.36.04, inv. nr 214, V 1-12-1903, no. 38.

58 NA, Koloniën, 1850-1900, 2.10.02, inv. nr 6510, MR 1894, 1157+ and inv. nr 6512, MR 1895, $240+$.

59 Jaarverslag Bangkatinwinning 1912: liv-lviii, 19. Probably this was also the cheapest solution.

60 Letter from Mentok, 30-3-1898, in: NA, Koloniën, 1850-1900, 2.10.02, inv. nr 6520, MR 1898, 3+; see also inv. nr 6518, MR 1896, 19+, 21+. As noted, Bangka continued to 'export' beriberi victims to Singapore, discharging them with a bit of pocket money. 
every opportunity to urge the mining kongsis to follow the rules he pointed to for preventing beriberi (however futile they might have been), and this official even mobilized the Lieutenant of the Chinese, not to mention two Catholic missionaries, to propagandize disinfection when they visited the mines. ${ }^{61}$ In any case, Pekelharing's idea of disinfecting all quarters and all clothing might have worked for the military, ships, or prisons, but not in the kongsis of Bangka, especially where buildings had dirt floors and coolies were lucky to have a single set of clothes.

In that same year, the leading mine engineer and a military pharmacist examined the tin ore and found 'microscopic worms (wurmpjes)'. Since the pharmacist insisted that these little worms were also found in the intestines of beriberi victims who were autopsied, the sick must be infecting themselves with parasites, transferring them to the water they used to wash ore, where they multiplied. Tell the miners, he proclaimed, to boil their drinking water. ${ }^{62}$ How could the miners take him seriously, when they themselves probably never drank water without boiling it. As early as 1852, it was well-known that, in the absence of tea, they drank an infusion made from leaves of jambu biji (guava) ${ }^{63}$ The admonition to boil water merely showed how ignorant the pharmacist and engineer were of the miners' life.

In 1888, care for the sick improved. Over six hundred patients (both miners and prisoners) were cared for in a provisional sick bay in Pangkal Pinang, most of them from Blinyu, where in one mine as many as 60 per cent of the labourers had been sick, presumably in spite of the wave of decontaminations. The authorities also recruited native medical personnel as caretakers. The government also built sick houses (ziekenloodsen) close to the mine sites but isolated from the other quarters (to prevent contagion). There the sick were to get 'improved food.' Prisons, another centre of the disease, were disinfected - as recommended. ${ }^{64}$

Still, how could it be that no one was looking at the diet of the coolies? The statistics show that beriberi continued and even grew after all the disinfecting activities. Furthermore, if the sick were getting better food, why wasn't better food available for all?

As Eijkman and his colleagues realized, rice needed examination. What kind of rice did the coolies eat and where did it come from?

61 NA, Koloniën, 1850-1900, 2.10.02, inv. nr 6441, MR 1884, 62.

62 NA, Koloniën, 1850-1900, 2.10.02, inv. nr 6443, MR 1884, 215. The idea of a parasite also appears in Erni (1884). Nasty parasites abounded, but they were not causing beriberi.

63 For example, ANRI, Bangka 3B/5, General Report 1852.

64 ANRI, Bangka 5/14, General Report 1888. 'Improved food' might have helped but many were too sick to eat. 


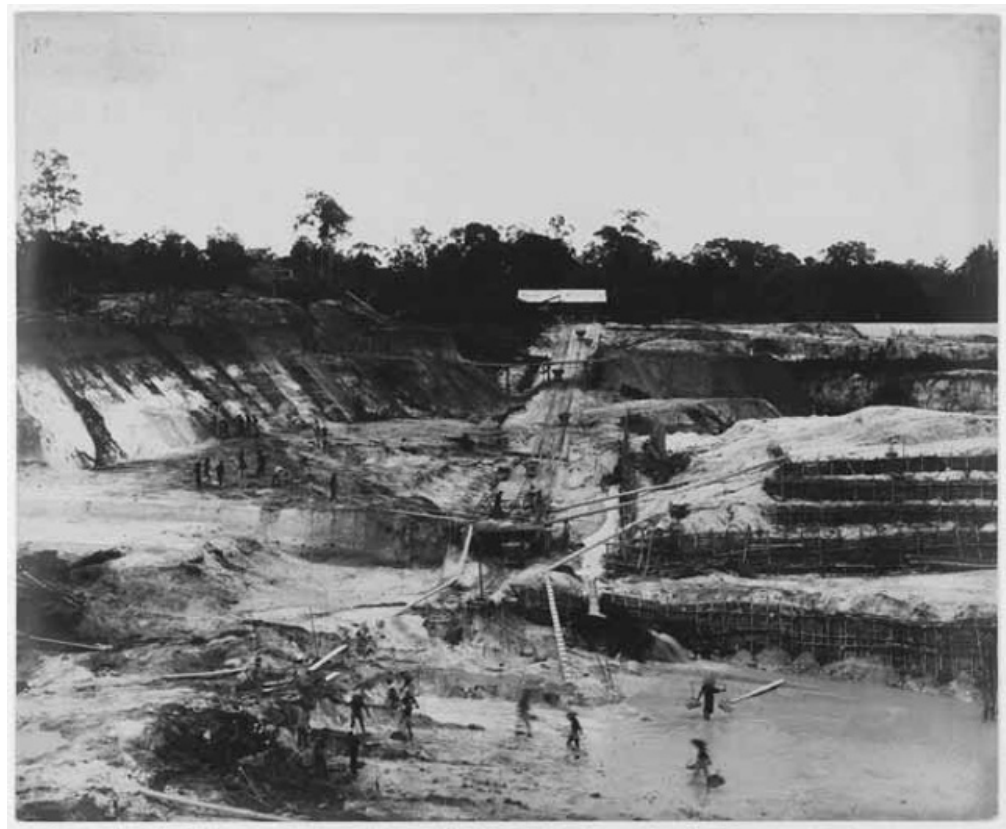

Figure 4. Tin mining in Blinyu, Bangka, circa 1920 (KITLV 34570)

\section{RICE IMPORTS}

Industrially milled rice dominated the imports to the islands. Some data is available for the 1880 s, when this rice came primarily from Java. In 1883, a shortfall in the local harvest necessitated imports of $765,000 \mathrm{~kg}$ from Singapore - in this year there is no record of imports from Java. ${ }^{65}$ In $1884400,000 \mathrm{~kg}$ milled rice was imported from Singapore and a small amount from Surabaya. ${ }^{66}$ In the following year new rules on provisioning mines put the job in the hands of local (mostly) Chinese traders, who imported from Batavia, Singapore and Palembang, apparently diversifying the suppliers. The other important part of the coolie diet, salt fish, was caught,

65 In addition to importing rice for non-miners in times of shortages, sailing ships to RiauLingga or even Singapore sometimes exported small amounts from local growers.

66 ANRI, Bangka 5/9, 5/10, General Reports 1883, 1884. 
bought, and salted on the island.$^{67}$ In 1885 , rice arrived from Java, Palembang, Singapore and Saigon, a new supplier, but apparently only about $50,000 \mathrm{~kg}$ from the latter. ${ }^{68} \mathrm{In} 1887,100,000 \mathrm{~kg}$ white rice arrived from Singapore, 370,000 from Batavia, 700,000 from Indramayu, 240,000 from Ceribon, 150,000 from Tanjungpandan, and 500,000 from Palembang (these statistics refer to the ports, not the producing areas, so the rice may have originated elsewhere). Smaller amounts came from Banten and Joana, while almost $140,000 \mathrm{~kg}$ brown rice came from Palembang and a small amount from Ceribon. ${ }^{6}{ }^{2}$ Why the amounts jumped so high after the previous year is unknown. Perhaps it had to do with shortfalls or with the opening of more storage capacity. Import figures for 1888 list over 3 million $\mathrm{kg}$ from Banten (a decimal error?), 300,000 from Batavia, 100,000 from Indramayu, 450,000 from Palembang, and smaller amounts from Ceribon, Joana, Tegal and Panarukan. Brown rice arrived from Palembang $(140,000)$ and a smaller amount from Batavia. Of more than 2 million kilograms of white rice imported in 1889, nearly half came from Indramayu and one third from Banten. In addition, $130,000 \mathrm{~kg}$ of brown rice came from Palembang and Banten. In 1890, Banten, Palembang and Indramayu, and also Ceribon were the major suppliers, and the ratio of white to brown rice was 10:1 or even higher for these years. However, in 1890 an additional 400,000 kg entered from Singapore - where it originated is unknown. ${ }^{70}$ By the beginning of the twentieth century, much - if not all - rice for the island was coming from Saigon's modern rice mills. ${ }^{71}$

Not just rice but food in general had become a problem. Repeated complaints about the quality of the coolies' diet reached the authorities, who were inclined to believe them. ${ }^{72}$ Batavia sent more examiners to assess the situation on Bangka. Following a rebellion of miners, accounts of bad treatment, and the increase of

67 ANRI, Bangka 5/11, General Report 1885. From 1885 to 1890, rice shipments from Saigon to the Netherlands Indies were interrupted, to be resumed in 1891, probably as a result of an official visit to Saigon. See Salmon 1994.

68 This figure may have a decimal error.

69 ANRI, Bangka 5/13, General Report 1887.

70 ANRI, Bangka 5/15 and 5/21, General Reports 1889 and 1890.

71 NA, Koloniën, Openbaar Verbaal, 1901-1952, 2.10.36.04, inv. nr 214, V 1-12-1903, no. 38. Interestingly, in 1897, the contract for delivering 120,000 piculs (almost 7,500,000 kg) of rice to the island was awarded to Khouw Kim An, later Majoor of the Chinese in Batavia (Letter of 1-6-1897, in: NA, Koloniën, 2.10.02, inv. nr 6519, MR 1897, 338+). According to Salmon 1994, the first steam-driven rice mill in Saigon was founded in 1869, and by the 1890 s there were five or six of these modern mills. Straits Chinese dominated the export of rice from Saigon, except that to China, which was mostly in Cantonese hands.

72 NA, Koloniën, Openbaar Verbaal, 1901-1952, 2.10.36.04, inv. nr 214, V 1-12-1903, no. 36. 
beriberi, as well as complaints about treatment of the sick sent to Bogor, B. Hoetink, an Officer for Chinese Affairs, visited the island in 1902 and produced a scathing criticism of the situation of workers for which he blamed the government as the responsible party. ${ }^{73}$

Bad food was a part of Bangka's bad reputation. De Jongh, a mine engineer sent to investigate in 1903, nevertheless claimed that all kongsis still maintained gardens and pigsties, feeding the animals with leftover rice or the remains of arak-brewing. For the coolies, some meat must have been available (although pork was a holiday food), and each day, fresh or salt vegetables complemented the rice and salt fish. ${ }^{74}$ De Jongh thought the food was adequate, but the small amounts of side-dishes in reality did not compensate for the lack of nutrients in the rice.

More years passed before Bangka's authorities implemented a first effective countermeasure. Grijns had shown that adding legumes to the diet could combat beriberi, and also D.J. Hulshoff Pol had underlined his results with a controlled experiment (above). At first it would appear that the tin mines fairly promptly implemented these insights (published in 1902 and 1904) in their prescribed diets. In November 1907, a visiting missionary noted that the miners in Blinyu received, in addition to rice, various vegetables, dried fish, and a portion of mung beans, "the latter as a preventive against beriberi' (Kortenhorst 1908:228). The statistics show that this must have been either not adequate or not universal, for the beriberi problem continued. Numbers of sick continued to climb, defying the work of Eijkman, Grijns, Vorderman, and Hulshoff Pol. What the scientists had learned, the administrators continued to ignore, for whatever reason.

As of 1914, Bangka's authorities finally moved, six years after this step was taken on Belitung. ${ }^{75}$ Only brown rice, zilvervliesrijst, was to be provisioned to the mines. ${ }^{76}$ Brown ('red') rice, imported from Java or Rangoon, would be the only form of rice distributed. The sick would continue to be treated in Mentok, which also improved the statistics. The general death rate among the miners dropped from over two per cent in 1906-1908 to one per cent in 1912-1913. The occasional later case of beriberi was of little significance.

73 NA, Koloniën, Openbaar Verbaal, 1901-1952, 2.10.36.04, inv. nr 214, V 1-12-1903, no. 38.

74 NA, Koloniën, Openbaar Verbaal, 1901-1952, 2.10.36.04, inv. nr 214, V 1-12-1903, no. 36.

75 In 1913, shortly before this move, the mining administration was separated from the general government administration and became a wholly government-owned company, Banka Tinwinning.

76 Jaarverslag Bankatinwinning 1913:19. Vorderman's statistical results were, as will be recalled, published in 1897. See also the directive Voorwaarden 1914. 
Although beriberi retreated and working conditions improved incrementally, other diseases would rise to take their place. When the death rate again climbed above two per cent in 1914, the major contributor was malaria, which caused more losses - above all lost work days - than beriberi ever had (Jaarverslag Bankatinwinning 1913:19-23). At least that could be fought, experts and administrators agreed, with mosquito nets.

\section{CONCLUSION: FALSE STEPS, FALSE CONCEPTIONS}

The history of knowledge conventionally focuses on breakthrough ideas and conceptual leaps. But the blind spots on the map, the dark continents of error and prejudice, carry their own mystery as well. How could so many intelligent people be so grievously wrong for such an extended period of time? How could they ignore so much overwhelming evidence that contradicted their most basic theories? These questions, too, deserve their own discipline - the sociology of error. ${ }^{77}$

One lesson from this account could be the need to move away from accepted ways of thinking. The medical breakthrough in ascribing diseases to 'germs' or 'filth' prevented many people from looking at the relationship of beriberi with diet, even though the role of food in treating or preventing beriberi had been part of common wisdom from very old times. Of course, changing and improving the coolies' diet would also have cost money (and probably effort). For a long time, this was not an alternative.

Another insight is the extent to which administrators and researchers were also often preoccupied with one disease at a time. Diseases have their day, it seems. When smallpox receded in the $1850 \mathrm{~s}$, beriberi gained prominence in the minds of officials and contributors to the Geneeskundig Tijdschrift voor Nederlandsch-Indië. Once the beriberi problem appeared solved, malaria became a focus.

Surely, however, another factor leading these men astray was the ease of ascribing something to poor hygiene - enabling, in a certain way, a 'blame the victim' diagnosis of the problem. 'Chinese are by nature dirty', officials noted, ${ }^{78}$ as if this excused the situation.

77 Johnson 2006:15. Johnson was referring to the dismal failures in London's 1854 cholera epidemic.

78 NA, Koloniën, Openbaar Verbaal, 1901-1952, 2.10.36.04, inv. nr 214, V 1-12-1903, no. 38. Even Hoetink underlined that conditions in Southern China were in any case not better than on Bangka. 
Susan Sontag (1990) once warned about the metaphorization of diseases, first tuberculosis, then cancer, finally AIDS. In the eyes of Western administrators and scientists, beriberi had become a metaphor for squalor. Coolies were assumed to be the 'dregs' of southern Chinese society. Indeed the miners lived in terrible poverty. Quarters were crowded and airless, the area around the barracks often filthy. Coolies were miserably clad, if they had not brought a blanket from China, the men covered themselves with used rice sacks when sleeping. A ready excuse appeared with the new arrivals from China, where, as everyone claimed to know, conditions were very poor, probably far worse (so the common perception) than in the mines.

A twentieth-century truism points out that if humans are treated in inhuman fashion, they become something less than human in the eye of the beholder. The concentration on filth and infection, or on importing the disease from China, in the end, offered an easier explanation for administrators than would a complete revision of the miners' diet - for which they themselves, who were responsible for supplying the rice, were to blame. Perhaps this 'epidemic' was also a metaphor for their callousness.

\section{REFERENCES}

\section{Unpublished sources}

Arsip Nasional Republik Indonesia, Jakarta

Bangka, General Reports

Nationaal Archief, The Hague

Ministerie van Koloniën, 1850-1900, nummer toegang 2.10.02

Ministerie van Koloniën, Openbaar Verbaal, 1901-1952, nummer toegang 2.10.36.04

\section{Published sources}

Abé, Yoshio

2007

Le 'décorticage' du riz; Typologie, réparition géographique et histoire des instruments à monder le riz. Paris: Éditions de la Maison des Sciences de l'Homme.

Berg, C.L. van den

1886 'Een bezoek aan het seminarie voor inlandsche zendelingen te Depok, naar aanleiding van daar voorgekomen gevallen van beri beri', Geneeskundig Tijdschrift voor Nederlandsch-Indië 25:57-66. 
Beri-beri

1854 'Beri-beri', Geneeskundig Tijdschrift voor Nederlandsch-Indië 3:514-9.

Boomgaard, Peter

2006

'The making and unmaking of tropical science; Dutch research on Indonesia, 1600-2000', Bijdragen tot de Taal-, Land- en Volkenkunde 162:191-217.

Carpenter, Kenneth J.

2000

Beriberi, white rice, and vitamin B; A disease, a cause, and a cure.

Berkeley, CA: University of California Press.

Corbin, Alain

1982 Le miasme et la jonquille; L'odorat et l'imaginaire social, XVIII ${ }^{-}$ XIX $X^{e}$ siècles. Paris: Aubier Montaigne.

Davisakd Puaksom

2007 'Of germs, public hygiene, and the healthy body; The making of the medicalizing state in Thailand', The Journal of Asian Studies 66-2:311-44.

Dieren, E. van

1887

Critiek op de beweringen van Prof. Pekelharing omtrent de beri-beri. Arnhem: Van der Zande.

1897 Beri-beri: eene rijstvergiftiging; Critisch-historische bijdrage tot de kennis der meelvergiften. Amsterdam: Scheltema and Holkema.

Diest, P. van

1865 Bangka, beschreven in reistogten. Amsterdam: Stemler.

Donath, W.F. and A.G. van Veen

1945 'A short history of beri-beri investigations in the Netherlands Indies', in: Pieter Honig and Frans Verdoorn (eds), Science and scientists in the Netherlands Indies, pp. 75-8. New York: Board for the Netherlands Indies, Surinam and Curaçao.

Erni, H.

1884 'Eene beri-beri epidemie op Sumatra', Geneeskundig Tijdschrift voor Nederlandsch-Indië 23:95-109.

Gedenkboek

1972

Gedenkboek Billiton, 1852-1927. Vol 2. 's-Gravenhage: Nijhoff. Gelpke, C.O.

1890

'Ein Beitrag zur Bestreitung der Beriberi', Geneeskundig Tijdschrift voor Nederlandsch-Indië 30:144-53.

Grist, D.H.

1955 Rice. London: Longmans, Green. 
Heerklotz, Dedo

1868 Reise und Aufenthalt in Niederländisch-Ostindien. Oederan: Schlesinger.

Heidhues, Mary F. Somers

1992

Bangka tin and Mentok pepper; Chinese settlement on an Indonesian island. Singapore: Institute of Southeast Asian Studies. [Social Issues in Southeast Asia.]

Herport, Albrecht

1930 Reise nach Java, Formosa, Vorder-Indien und Ceylon, 16591668. Haag: Nijhoff. [Reisebeschreibungen von Deutschen Beamten und Kriegsleuten im Dienst der Niederländischen West- und Ost-Indischen Kompagnien 1602-1797]

Heijden, H.N. van der

1918 'De hygiënische verzorging der arbeiders-immigranten in de Buitenbezittingen', Koloniale Studiën 2:45-84.

Jansen, B.C.P.

1959

Het levenswerk van Christiaan Eijkman, 1858-1930. Haarlem:

Bohn. [Published in honour of the centenary of the Association for the Nederlandsch Tijdschrift voor Geneeskunde, 18571957.]

Johnson, Steven 2006

The ghost map; The story of London's most terrifying epidemic, and how it changed science, cities, and the modern world. New York: Riverhead Books.

Kappen, E.F.J. van

1860

'Beri-beri onder de mijnwerkers in het distrikt Soengeislan (Eiland Banka)', Geneeskundig Tijdschrift voor NederlandschIndië 10:510-7.

Kortenhorst, A.S.J.

1908

'Vormreis van Monseigneur E.S. Luypen naar het eiland Banka', Berichten uit Nederlandsch-Oost-Indië voor de leden van den Sint Claverbond 20:211-29.

1909

'Vormreis van Monseigneur E.S. Luypen naar het eiland

Banka', Berichten uit Nederlandsch-Oost-Indië voor de leden van den Sint Claverbond 21:3-30.

Langen, C.D. de

Beri-beri; Een klinische studie van voeding en ziekte in NederlandschIndie. 's-Gravenhage: Naeff.

Latham, A.J.H.

1998 Rice; The primary commodity. London: Routledge. 
Leent, F.J. van

1880

'Mededeelingen over beri-beri', Geneeskundig Tijdschrift voor Nederlandsch-Indië 20:272-310.

Lindman, L.

1854 'Beschrijving der op het eiland Banka waargenomene beriberi gedurende het jaar 1853', Tijdschrift der Vereeniging tot Bevordering der Geneeskundige Wetenschappen in NederlandschIndie 3:131-59.

Pekelharing, C.A.

1888

'Mededeelingen omtrent de stand van het onderzoek naar de oorzaak en het wezen der beri-beri', Geneeskundig Tijdschrift voor Nederlandsch-Indï̈ 27:121-50.

Posewitz, T.

1886 'Die Zinninseln im Indischen Ozean: Part II: Das Zinnvorkommen und die Zinngewinning in Bangka', Földtani Intézet (Jahrbuch der Ungarischen Geologischen Reichsanstalt) 8:57.

Salmon, Claudine

1994 'De Batavia à Saïgon; Notes de voyage d'un marchand chinois (1890)', Archipel 47:155-191.

Scheube, B.

1894

Die Beriberi-Krankheit; Eine geographisch-medicinische Studie. Jena: Fischer.

1896 Die Krankheiten der warmen Länder; Ein Handbuch für Ärzte. Jena: Fischer.

Sontag, Susan

$1990 \quad$ Illness as metaphor and AIDS and its metaphors. New York: Anchor Doubleday.

Swaving, C.

1871

'Een woord over een kongsiehuis en de sterfte onder de mijnwerkers op Billiton', Geneeskundig Tijdschrift voor Nederlandsch-Indï 14:1-16.

Terwiel, B.J.

1983

A history of modern Thailand, 1767-1942. St Lucia/London/ New York: University of Queensland Press.

Vierde schipvaart

De vierde schipvaart der Nederlanders naar Oost-Indië onder Jacob Wilkens en Jacob van Neck, (1599-1604). Uitgegeven door H.A. van Foreest en A. de Booy. Vol. 1. 's-Gravenhage: Nijhoff. [Werken uitgegeven door de Linschoten-Vereeniging 82.] 
Voorwaarden

1914

Voorwaarden van aanbesteding voor de levering van rijst in zilvervlies ten behoeve van de mijnwerkers op het eiland Banka. Batavia: Landsdrukkerij.

Wijckerheld Bisdom, R.F.J.

1911

'Overzicht van het totaal aantal overledenen en van de met malariaziekten en beri-beri behandelde, afgekeurde en aan die ziekten overleden militairen van het NederlandschIndische Leger gedurende de jaren 1885 tot en met 1909', in: Feestbundel ter herinnering uitgegeven bij het verschijnen van het 50ste deel Geneeskundig Tijdschrift voor Nederlandsch-Indie, pp. 395-403. Batavia: Javasche Boekhandel en Drukkerij. [Uitgegeven door de Vereeniging tot Bevordering der Geneeskundige Wetenschappen in Nederlandsch-Indie.]' 